\title{
Description of a new genus and new species of freshwater crab (Brachyura: Gecarcinucidae) from the Western Ghats, Kerala, India
}

\author{
Sameer Kumar Pati ${ }^{*}$ and Arath Raghavan Sudha Devi ${ }^{2}$
}

\begin{abstract}
Background: Freshwater crabs of the Western Ghats have been severely underestimated in their diversity. Since freshwater crabs have a small spatial scale endemism, many remote and poorly studied localities in the Western Ghats need to be surveyed. In this study, a new genus and new species is described.

Results: Arcithelphusa cochleariformis gen. et sp. nov. is described from Ondayangadi, Wayanad district, Kerala, India. The new genus and new species is exceptional among Indian freshwater crabs due to its squarish, highly arched carapace, appearing box-like in frontal view, and long, stout, spoon-shaped male first gonopod.

Conclusions: With the current discovery, 14 genera and 36 species of gecarcinucid freshwater crabs are recognized in the Western Ghats of India. More new taxa can be expected from this exceptionally biodiversity-rich area if the necessary surveys are done.
\end{abstract}

Keywords: Crustacea; Decapoda; Gecarcinucidae; Freshwater crab; Taxonomy; Ecology; New genus; New species; Western Ghats; India

\section{Background}

About 35 species of freshwater crabs under 13 genera were so far reported from the Western Ghats of India (Alcock 1910; Roux 1931; Bott 1970; Bahir and Yeo 2007; Pati and Sharma 2013, 2014a, b; Klaus et al. 2014). In fact, the diversity of freshwater crabs is severely underestimated in the Western Ghats, a biodiversity 'hotspot' with exceptional freshwater diversity and endemism (Raghavan et al. 2014). This fact is evident from the discovery of a new genus and five new species during the last few years (Pati and Sharma 2013, 2014a; Klaus et al. 2014). Many areas of the Western Ghats were not well explored for freshwater crab diversity, and this is partly due to the difficulty in accessing remote localities. Since small spatial scale endemism is seen in freshwater crabs (Klaus et al. 2014), many remote and poorly studied localities in the Western Ghats need to be surveyed.

Recently, some freshwater crabs were collected from the Western Ghats of Kerala. After careful examination of the

\footnotetext{
* Correspondence: sameer_pati@yahoo.co.in

${ }^{1}$ Zoological Survey of India, Western Regional Centre, Vidyanagar, Sector 29, P.C.N.T. Post, Akurdi, Pune 411 044, Maharashtra, India

Full list of author information is available at the end of the article
}

carapace morphology and male gonopod structures, these crabs were recognized as a new species in a new genus, Arcithelphusa. The specimens were compared with the species of morphologically related genera, Ghatiana Pati \& Sharma, 2014 [type species: Ghatiana aurantiaca Pati \& Sharma, 2014, by original designation; gender feminine], Globitelphusa Alcock, 1909 [type species: Paratelphusa (Globitelphusa) bakeri Alcock, 1909, by original designation; gender feminine], Gubernatoriana Bott, 1970 [type species: Paratelphusa (Globitelphusa) gubernatoris Alcock, 1909, by original designation; gender feminine], Inglethelphusa Bott, 1970 [type species: Paratelphusa (Globitelphusa) fronto Alcock, 1909, by original designation and monotypy; gender feminine], Pilarta Bahir \& Yeo, 2007 [type species: Pilarta anuka Bahir and Yeo, 2007, by original designation and monotypy; gender feminine] and Snaha Bahir \& Yeo, 2007 [type species: Snaha aruna Bahir and Yeo, 2007, by original designation; gender feminine].

\section{Methods}

Crab specimens were collected from shallow to deep burrows adjacent to water channels in betel nut plantations at Ondayangadi, about $5 \mathrm{~km}$ northeast of Mananthavady in 
Wayanad district of Kerala (Figure 1). Specimens were preserved in 95\% ethyl alcohol and deposited in the National Zoological Collections (NZC) of Zoological Survey of India (ZSI), Western Regional Centre (WRC), Pune. Measurement methods and terminology follow $\mathrm{Ng}$ and Tay (2001). Abbreviations used are as follows: cw, carapace width; cl, carapace length; ch, carapace height; fw, frontal width; S2 to S4, thoracic sternites 2 to 4, respectively; G1, male first pleopod; G2, male second pleopod; and P2 to P5, pereiopods 2 to 5, respectively.

\section{Results}

\section{Taxonomy}

Family Gecarcinucidae Rathbun, 1904

\section{Arcithelphusa gen. nov.}

Type species. Arcithelphusa cochleariformis sp. nov., by present designation.

Diagnosis. Carapace smooth, squarish $(\mathrm{cl} / \mathrm{cw}=0.9)$, highly arched $(\mathrm{ch} / \mathrm{cw}=0.7)$, box-like in frontal view; anterolateral margin with short, oblique striations; epigastric cristae and postorbital cristae indistinct; external orbital angle poorly developed; epibranchial tooth indistinct; branchial regions inflated; cervical grooves shallow; $\mathrm{H}-$ shaped gastric groove visible; front narrow, 0.25 times $\mathrm{cw}$, without frontal median triangle; epistomal median lobe lacking median tooth (Figures 2A,B and 3A,B). Suture between male thoracic sternites S2, S3 prominent, deep, not reaching lateral margins and between $\mathrm{S} 3$, S4 prominent, deep, reaching lateral margins (Figures $2 \mathrm{C}$ and $3 \mathrm{C}$ ). Male abdomen narrowly triangular; sixth abdominal somite distinctly broader than long, shorter than telson, lateral margins slightly convex; telson longer than broad, narrowly triangular, with slightly concave outer margins, apex acutely triangular (Figures $2 \mathrm{C}$ and 3D). Third maxilliped exopod lacking flagellum (Figure 3E). G1 long, stout, appearing as lateral view of spoon in both dorsal and lateral views; terminal segment cylindrical, short, 0.30 times length of subterminal segment, curved more outward at mid-length towards dorsal side; subterminal segment basal half distinctly broader than distal half (Figures 2D,E,F and 3F,G,H). G2 with very short distal segment, 0.2 times length of basal segment (Figures $2 \mathrm{G}$ and $3 \mathrm{I}$ ).

Etymology. The genus name, derived from Arca (Latin for 'box') in combination with the genus name Thelphusa, alludes to the highly inflated carapace of the crab, appearing box-like in frontal view. Gender is feminine.

Ecological notes. These crabs dwell in shallow to deep burrows along water channels of betel nut plantations (Figure 4), banana farms and rice field embankments (A.R. Sudha Devi, unpublished data).

Distribution. At present, the genus is known only from the Western Ghats in Wayanad district of Kerala.

\section{Arcithelphusa cochleariformis sp. nov.}

Type material. India: adult male, holotype (cw $30.76 \mathrm{~mm}, \mathrm{cl}$ $26.30 \mathrm{~mm}$, ch $21.46 \mathrm{~mm}$, fw $7.60 \mathrm{~mm}$ ), Ondayangadi, $5 \mathrm{~km}$ northeast of Mananthavady, Wayanad district, Kerala $\left(11.8231649^{\circ} \mathrm{N}\right.$ and $\left.76.0232338^{\circ} \mathrm{E}\right)$, altitude $767 \mathrm{~m}, 25$ June 2011, coll. M.K. Smija (ZSI, WRC-C.1188); paratypes, three males (cw 27.28 to $32.20 \mathrm{~mm}$, cl 22.56 to $26.94 \mathrm{~mm}$, ch 19.36 to $21.38 \mathrm{~mm}$, fw 7.20 to $7.68 \mathrm{~mm}$ ), one female (cw $26.76 \mathrm{~mm}$, cl $22.90 \mathrm{~mm}$, ch $19.22 \mathrm{~mm}$, fw $7.06 \mathrm{~mm}$ ), same collection data as holotype (ZSI, WRC-C.1189); five males (cw 23.94 to $28.84 \mathrm{~mm}, \mathrm{cl} 20.50$ to $23.80 \mathrm{~mm}$, ch 17.06 to $21.14 \mathrm{~mm}$, fw 6.34 to $7.46 \mathrm{~mm}$ ), one female (cw $32.26 \mathrm{~mm}$, cl

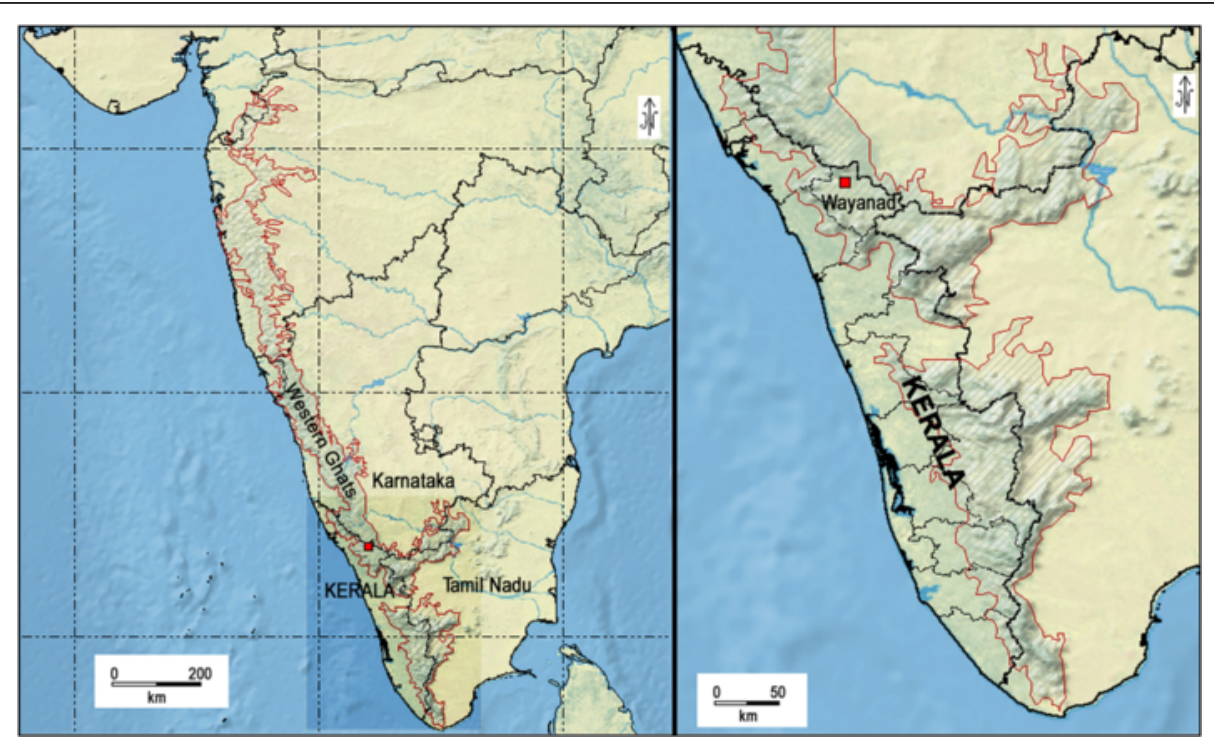

Figure 1 Map of collection site (red square mark) of Arcithelphusa cochleariformis sp. nov. 

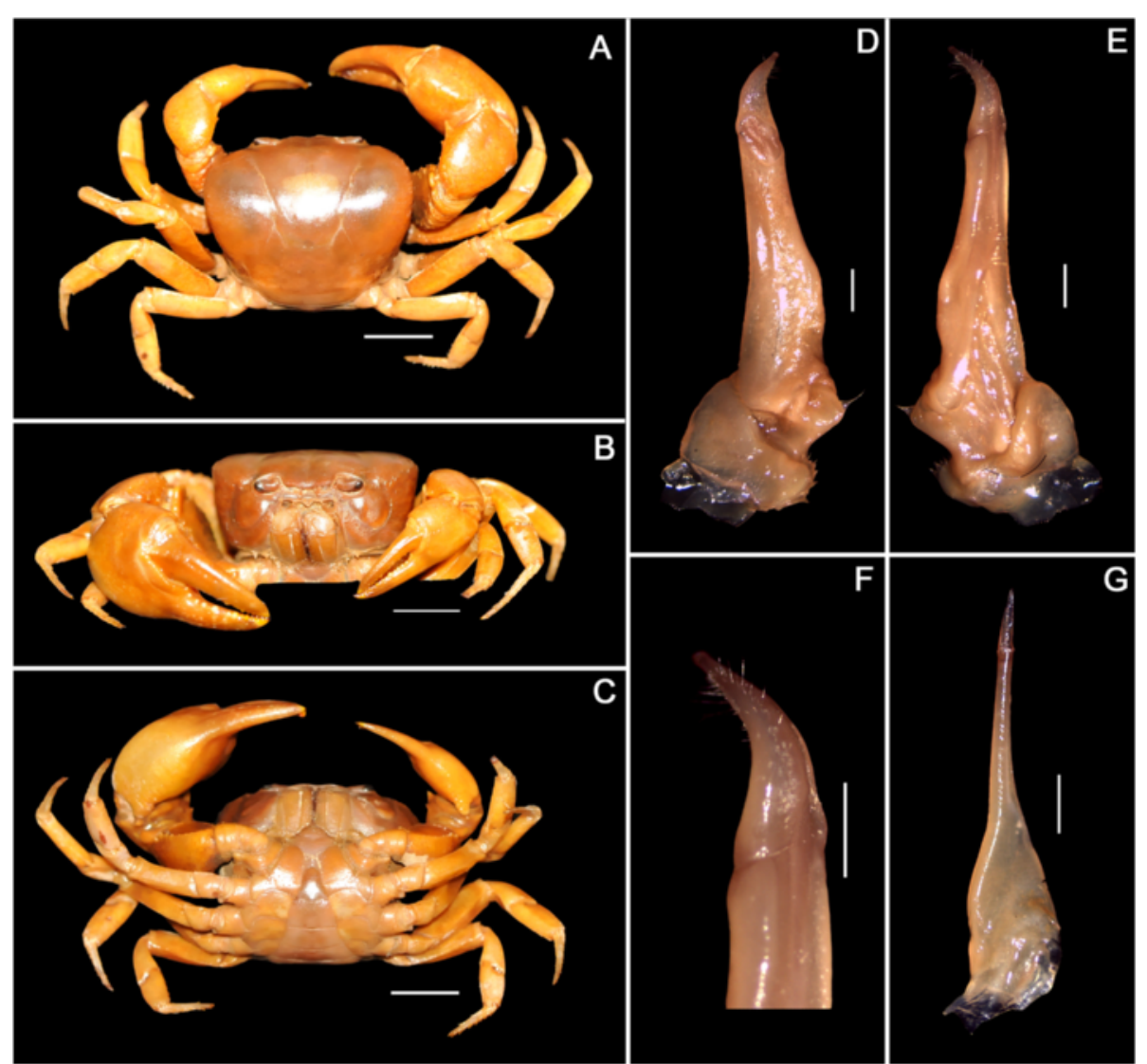

Figure 2 Arcithelphusa cochleariformis sp. nov., holotype male (ZSI, WRC-C.1188). (A) Carapace, dorsal view; (B) carapace, frontal view; (C) carapace, ventral view; (D) right G1, dorsal view; (E) right G1, lateral view; (F) right G1 terminal segment, lateral view; (G) right G2. Scale bars = $10 \mathrm{~mm}(\mathbf{A}-\mathrm{C})$ and $1 \mathrm{~mm}(\mathrm{D}-\mathrm{G})$.

$25.76 \mathrm{~mm}$, ch $22.24 \mathrm{~mm}$, fw $7.40 \mathrm{~mm}$ ), Ondayangadi, $5 \mathrm{~km}$ northeast of Mananthavady, Wayanad district, Kerala $\left(11.82463552^{\circ} \mathrm{N}\right.$ and $\left.76.03024006^{\circ} \mathrm{E}\right)$, altitude $760 \mathrm{~m}, 16$ November 2013, coll. Ammini (ZSI, WRC-C.1190).

Diagnosis. As for genus.

Description of holotype. Carapace smooth, squarish $(\mathrm{cl} /$ $\mathrm{cw}=0.9)$, highly arched $(\mathrm{ch} / \mathrm{cw}=0.7)$, box-like in frontal view; anterolateral carapace highly inflated in frontal view; anterolateral margin with distinct, oblique, short striations; posterolateral margin with fine, oblique, short striations; epigastric cristae indistinct, represented by two lumps; postorbital cristae indistinct; external orbital angle small, poorly developed; epibranchial tooth indistinct; postorbital region flat; branchial regions inflated; subhepatic region slightly rugose; cervical grooves narrow, shallow, slightly broad anteriorly, almost reaching to level of postorbital cristae; mesogastric groove narrow, shallow, bifurcated posteriorly; H-shaped gastric groove visible; front smooth, flat, narrow, 0.25 times $\mathrm{cw}$, without frontal median triangle; epistomal median lobe triangular, lacking median tooth (Figures 2A,B and 3A,B).

Chelipeds smooth, highly unequal, left chela larger; palm of larger chela almost equal in length to height and length of dactylus; teeth on fingers of both chelipeds blunt with four or five enlarged teeth on fingers of larger chela; distinct gap when fingertips of larger chela are in contact; tip of fingers blunt; carpal spine distinct, slightly blunt; outer surface of merus rugose (Figure 2A,B,C).

Ambulatory legs (P2 to P5) smooth, slender; dactylus equal in length to propodus; longest propodus (P3) twice as long as broad (Figure 2A,C).

Suture between male thoracic sternites S2, S3 prominent, deep, not reaching lateral margins and between S3, S4 prominent, deep, reaching lateral margins (Figures $2 \mathrm{C}$ and $3 \mathrm{C}$ ).

Male abdomen narrowly triangular; sixth abdominal somite distinctly broader than long, shorter than telson, lateral margins slightly convex; telson longer than broad, narrowly triangular, with slightly concave outer margins, apex acutely triangular; male sternoabdominal cavity deep, long, reaching imaginary line joining bases of chelipeds (Figures 2C and 3D).

Mandibular palp with two joints, terminal joint bilobed. Exopod of first, second maxillipeds each with long flagellum. Exopod of third maxilliped lacking flagellum, longer than ischium; ventral sulcus of ischium deep, long, parallel to inner margins and towards inner sides; depression on merus towards inner sides (Figure 3E). 


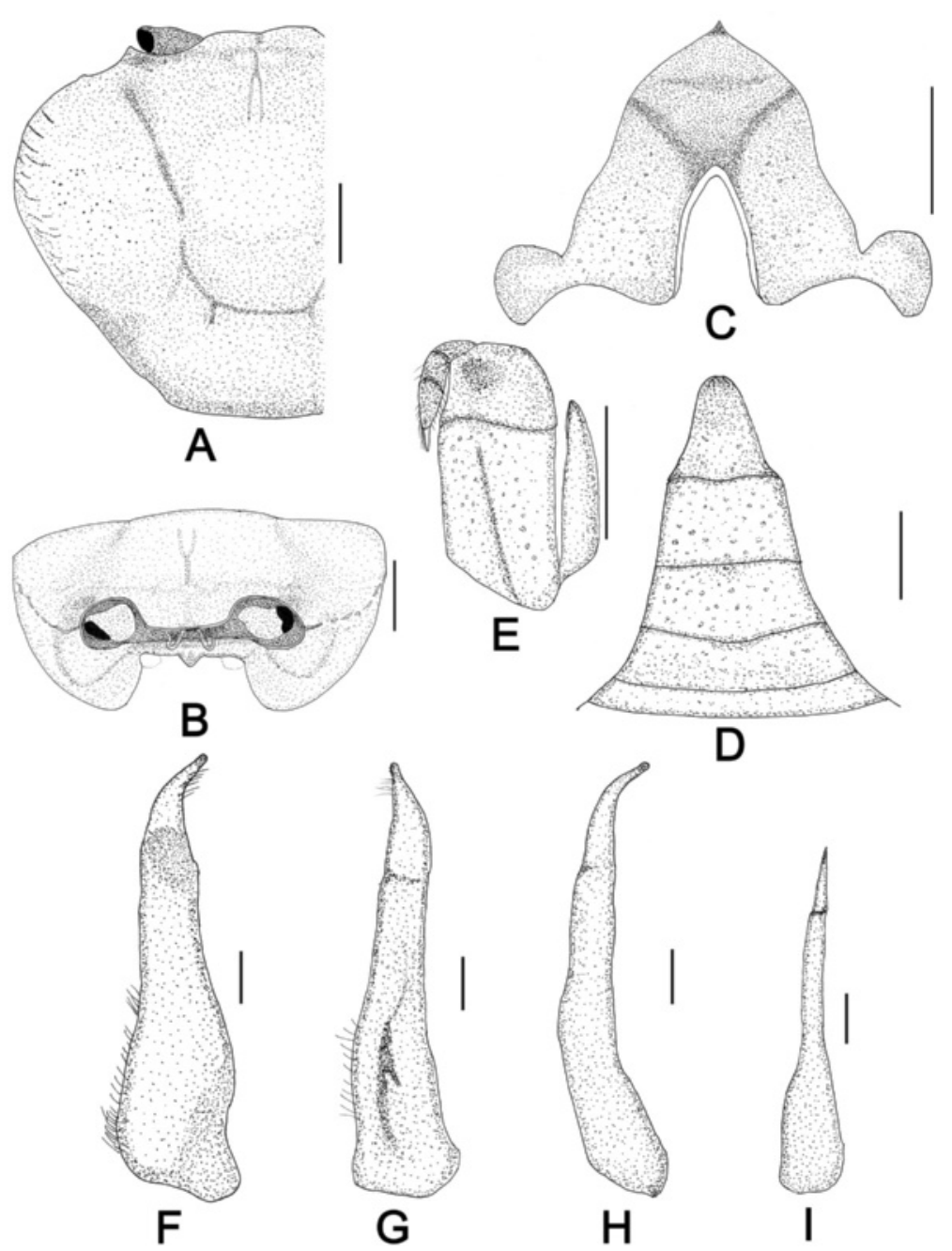

Figure 3 Arcithelphusa cochleariformis sp. nov., holotype male (ZSI, WRC-C.1188). (A) Carapace (left half), dorsal view; (B) carapace, frontal view; (C) anterior male thoracic sternites; (D) male abdomen; (E) left third maxilliped; (F) right G1, dorsal view; (G) right G1, ventral view; (H) right G1, lateral view; (I) right $\mathrm{G} 2$. Scale bars $=5 \mathrm{~mm}(\mathrm{~A}-\mathrm{E})$ and $1 \mathrm{~mm}(\mathrm{~F}-\mathrm{I})$.

G1 long, stout, appearing as lateral view of spoon in both dorsal and lateral views, with short, cylindrical terminal segment, 0.30 times length of subterminal segment; terminal segment curved more outward at mid-length towards dorsal side, tip narrow, blunt; subterminal segment basal half broader than distal half (Figures 2D,E,F and 3F,G,H). G2 short, with very short distal segment, 0.2 times length of basal segment (Figures $2 \mathrm{G}$ and $3 \mathrm{I}$ ).

Colour. In life, carapace dark brown, chelipeds and ambulatory legs light brown.

Type locality. Ondayangadi, $5 \mathrm{~km}$ northeast of Mananthavady, Wayanad district, Kerala, India (11.8231649 $\mathrm{N}$ and $76.0232338^{\circ} \mathrm{E}$ ) (altitude $767 \mathrm{~m}$ ).

Paratypes. The paratypes do not differ much from the holotype in carapace morphology and G1 structure. However, minor differences were observed in carapace morphology of some specimens. In one paratype (ZSI, WRC-
C.1190, largest male), the epistomal median lobe is broadly triangular in opposition to triangular epistomal median lobe in the holotype and other paratypes. The right chela is comparatively large in five male and two female paratypes ranging from smallest to largest size. In most of the paratypes (seven males and one female), the fingertips are blunt to sharp. Colour variations were noted among the paratypes (except male specimens of ZSI, WRC-C.1189): one female paratype (ZSI, WRC-C.1189) with dark brown carapace, and brown chelipeds and ambulatory legs; one paratype (ZSI, WRCC.1190, largest male) has a yellowish brown dorsal surface medially, dark to reddish brown on the sides, and with mainly reddish brown chelipeds and ambulatory legs; the rest of the paratypes (ZSI, WRC-C.1190) have reddish brown carapaces, chelipeds and ambulatory legs.

Etymology. The species epithet is derived from cochleariformis (Latin for 'spoon-shaped'), referring to the shape of 


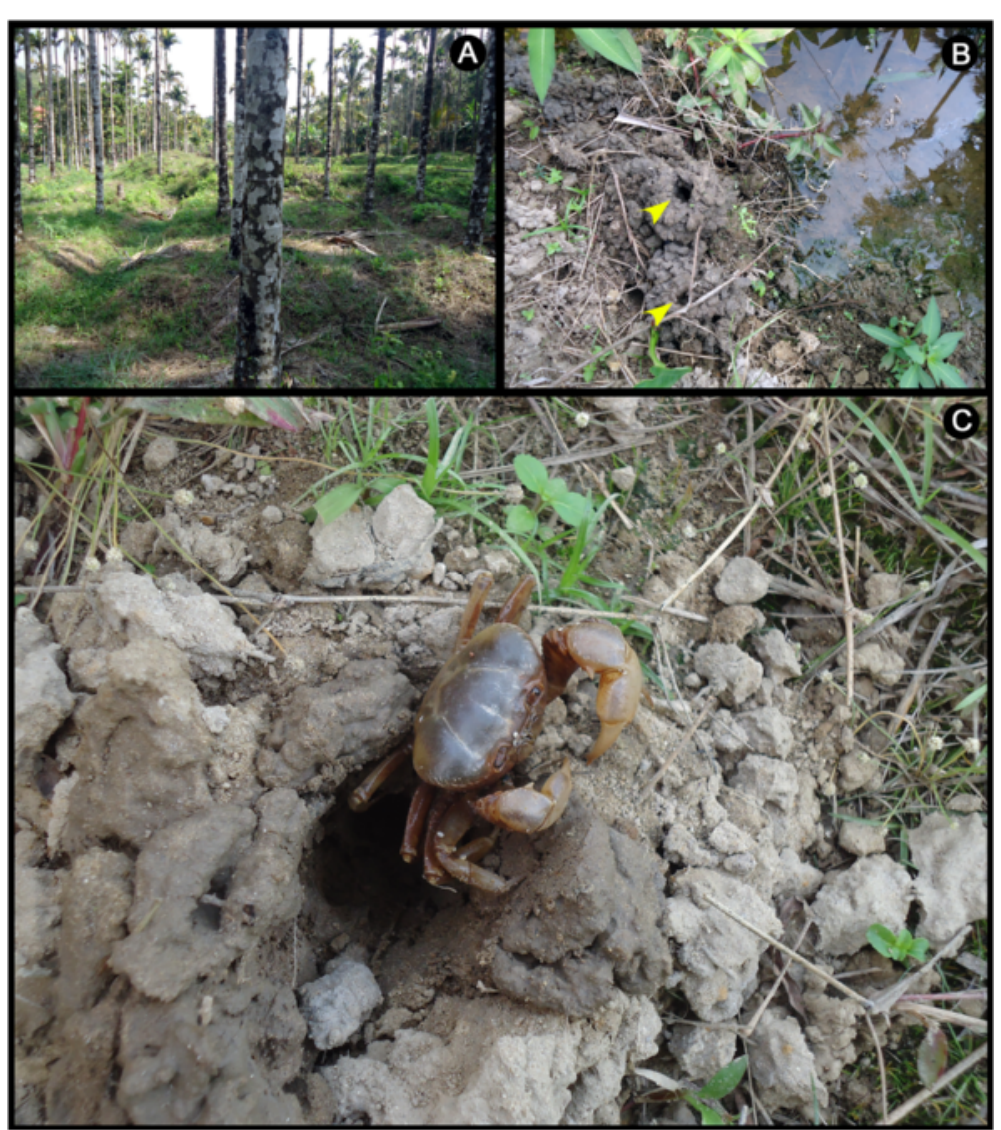

Figure 4 Habitat of Arcithelphusa cochleariformis sp. nov. at type locality, Ondayangadi. (A) Betel nut plantations; (B) burrows along water channels (yellow arrow head marks); (C) live crab near a burrow.

the first male gonopod in dorsal and lateral views that resembles lateral view of a spoon.

Ecological notes. Specimens were found in shallow to deep burrows along the water channels of betel nut plantations (Figure 4), which were once rice fields (A.R. Sudha Devi, unpublished data). Forest or grasslands were the natural habitats for the new species before their conversion to rice fields. These semi-terrestrial crabs dwell in burrows adjacent to water channels or away from it in open or shaded areas of the banana and betel nut plantations. These crabs are also found in marshy lands and along the paddy field embankments. Normally, their burrow openings are surrounded by wet clods (Figure 4B,C). The burrows are waterlogged during rainy season whereas the burrow openings are sealed with mud during dry seasons in order to maintain humidity inside.

Arcithelphusa cochleariformis is an omnivore species, which mainly feeds on a wide range of plant material (grasses, aquatic vegetation, leaves of colocasia, green algae, creepers and areca nut shells), earthworms and insects (grasshoppers, brown planthoppers and praying mantes) (A.R. Sudha Devi, unpublished data). They also survive on decaying leaves and detritus. Decayed leaves and remnants of food material are often seen accumulated near their burrows. Juvenile crabs prefer aquatic plants, grasses, green algae, moss plants, insect larvae, decayed leaves and detritus as their food. These crabs are mainly nocturnal and are found active during early morning and night. They very rarely forage during the day time. Adult crabs prefer to stay inside the burrows while juveniles mostly spend their time in water. Their predators include birds (herons and egrets) and mammals (wild boars, mongooses and cats). The new species was sympatric with Vela carli (Roux, 1931).

Distribution. The species is presently known only from the type locality, Ondayangadi and other localities of Wayanad district in Kerala (Table 1).

\section{Discussion}

Arcithelphusa is a monotypic genus and is immediately distinguished from all other Indian gecarcinucid genera except Ghatiana, Globitelphusa, Gubernatoriana, Inglethelphusa, Pilarta and Snaha by the absence of a flagellum on the third maxilliped exopod (Figure 3E). The flagellum on the exopod of the third maxilliped is also absent or vestigial in Ghatiana, Globitelphusa, Gubernatoriana, Inglethelphusa, Pilarta and Snaha (see Pati and Sharma 2014a: Figures three (D), 
Table 1 Distribution of Arcithelphusa cochleariformis sp. nov. in Wayanad district, Kerala

\begin{tabular}{|c|c|c|c|c|}
\hline Locality & Latitude $(\mathrm{N})$ & Longitude (E) & Altitude (m) & Habitat \\
\hline Bavali & $11.8520258^{\circ}$ & $76.1138744^{\circ}$ & 709 & Paddy fields \\
\hline Chettapalam & $11.7981135^{\circ}$ & $76.191415^{\circ}$ & 752 & Paddy fields \\
\hline Ellumannam & $11.7867502^{\circ}$ & $75.9622899^{\circ}$ & 755 & Paddy fields \\
\hline Kambalakkad & $11.6756376^{\circ}$ & $76.0754501^{\circ}$ & 789 & Betel nut plantations \\
\hline Muthanga & $11.6690787^{\circ}$ & $76.3695167^{\circ}$ & 864 & Paddy fields \\
\hline Ondayangadi (type locality) & $11.8231649^{\circ}$ & $76.0232338^{\circ}$ & 767 & Betel nut plantations and paddy fields \\
\hline Padinjarathara & $11.685401^{\circ}$ & $75.974814^{\circ}$ & 753 & Betel nut plantations \\
\hline Pakkom & $11.8020239^{\circ}$ & $76.1015508^{\circ}$ & 724 & Paddy fields \\
\hline Panamaram & $11.74057^{\circ}$ & $76.07579^{\circ}$ & 724 & Betel nut plantations and paddy fields \\
\hline Thirunelly & $11.9081185^{\circ}$ & $75.9971183^{\circ}$ & 809 & Paddy fields \\
\hline
\end{tabular}

five (D) for Ghatiana, Figure seven (D) for Gubernatoriana; Alcock 1910: Plate 8, Figure thirty-one (b) for Globitelphusa, Plate 9, Figure thirty-four (b) for Inglethelphusa; Bahir and Yeo 2007: Figure twenty-five (B) for Pilarta, Figure twentyseven (A) for Snaha). However, the highly arched carapace with a narrow front and the prominently curved G1 terminal segment easily distinguish the new genus from Ghatiana, Globitelphusa, Gubernatoriana, Inglethelphusa, Pilarta and Snaha (Figures 2B,D,E,F and 3B,F,H; see Pati and Sharma 2014a: Figures two (B), three (E), four (B), five (E) for Ghatiana; Bott 1970: Plate 33, Figures thirteen, fifteen for Globitelphusa; Pati and Sharma 2014b: Plate 7, Figure seven (B,D), Plate 8, Figure eight (B,D) for Gubernatoriana, Plate 9, Figure nine (B,D) for Inglethelphusa; Bahir and Yeo 2007: Figures twenty-five (F), twenty-six (B) for Pilarta, Figures twenty-seven (C), twenty-eight (B) for Snaha). Further, the prominent and deep suture between thoracic sternites S2, S3 and S3, S4 separates the new genus from the above genera except Snaha (Figures 2C and 3C; see Bahir and Yeo 2007: Figures twenty-eight (C), twenty-nine (A)). As in the genera Ghatiana, Gubernatoriana (except G. basalticola Klaus, Fernandez \& Yeo, 2014) and Inglethelphusa, the G2 distal segment of the new genus is short (Figures 2G and 3I; see Pati and Sharma 2014a: Figures three $(\mathrm{H})$, five $(\mathrm{H})$ for Ghatiana; Pati and Sharma 2014b: Plate 7, Figure seven (F), Plate 8, Figure eight (F) for Gubernatoriana, Plate 9, Figure nine (F) for Inglethelphusa) whereas Globitelphusa, Pilarta and Snaha have a long G2 distal segment (see Bahir and Yeo 2007: Figure twenty-five (H) for Pilarta, Figures twenty-seven (G), twenty-nine (E) for Snaha). The recently described species, G. basalticola, has an elongated G2 distal segment and more wide frontal margin, indicating that the species should be placed in a new genus (Klaus et al. 2014). Other than its short to vestigial G2 distal segment, Arcithelphusa also resembles Ghatiana, Gubernatoriana and Inglethelphusa in its squarish appearance of the carapace (Figure 2A; see Pati and Sharma 2014a: Figures two (A), four (A) for Ghatiana; Pati and Sharma 2014b: Plate 7, Figure seven (A), Plate 8, Figure eight (A) for Gubernatoriana, Plate 9, Figure nine (A) for Inglethelphusa). Nonetheless, the new genus is distinguished from Ghatiana, Gubernatoriana and Inglethelphusa by the narrowly triangular male abdomen and distinctly curved, comparatively short G1 terminal segment, 0.3 times the length of the subterminal segment (Figures 2C,D and 3D,F) (vs. the T-shaped male abdomen and slightly curved to straight, comparatively long G1 terminal segment, 0.35 to 0.80 times the length of the subterminal segment) (see Pati and Sharma 2014a: Figures two (C), three (B,E), four (C), five (B,E) for Ghatiana; Pati and Sharma 2014b: Plate 7, Figure seven (C,D), Plate 8, Figure eight (C,D) for Gubernatoriana, Plate 9, Figure nine (C,D) for Inglethelphusa).

The new genus is also similar to the genus Cylindrotelphusa Alcock, 1909 in some carapace morphology and male gonopod structures, notably in the highly convex carapace, narrow front, small external orbital angle, narrowly triangular male abdomen, narrowly triangular telson with concave outer margins and an acutely triangular apex, highly curved G1 terminal segment, and short G2 distal segment (Figures 2A,B,C,D,E,F,G and 3B,D,F,H,I; see Bahir and Yeo 2007: Figures four (A,D), five $(A, B, C)$ ). However, the new genus, in addition to lacking a flagellum on the third maxilliped exopod, can be differentiated from Cylindrotelphusa by the relatively squarish $(\mathrm{cl} / \mathrm{cw}=0.9)$ and more convex carapace $(\mathrm{ch} / \mathrm{cw}=0.7)$, striated anterolateral margin, indistinct postorbital cristae, indistinct epibranchial tooth, prominent and deep suture between thoracic sternites S2, S3 and S3, S4, stout G1 with a distinctly curved, short terminal segment, 0.3 times the length of the subterminal segment (Figures 2A,C,D and 3A,C,F) [vs. the relatively transverse $(\mathrm{cl} / \mathrm{cw}=0.8)$ and less convex carapace $(\mathrm{ch} /$ $\mathrm{cw}=0.5$ ), serrated anterolateral margin, distinct postorbital cristae, small, blunt epibranchial tooth, less prominent and shallow suture between thoracic sternites S2, S3 and S3, S4, slender G1 with a sickle-shaped, long terminal segment, 0.55 times the length of the subterminal segment] (see Bahir and Yeo 2007: Figures four (A), five (A,C)). Arcithelphusa cochleariformis, new species, is highly distinct among 
the other Indian freshwater crabs due to its squarish, highly arched carapace, appearing box-like in frontal view, and long, stout, spoon-shaped G1. The new species is morphologically similar to Cylindrotelphusa steniops, particularly due to its deep carapace, narrow front, poorly developed external orbital angle, prominently curved G1 terminal segment and short G2 distal segment. However, both the species are markedly different in many other morphological features as discussed above.

Altogether, 14 genera and 36 species of gecarcinucid freshwater crabs are now found in the Western Ghats of India: Arcithelphusa gen. nov. [A. cochleariformis sp. nov.]; Baratha Bahir \& Yeo, 2007 [B. peena Bahir \& Yeo, 2007, B. pushta Bahir \& Yeo, 2007]; Barytelphusa Alcock, 1909 [B. cunicularis (Westwood, 1836), B. guerini (H. Milne Edwards, 1853), B. mccanni (Chopra \& Das, 1935)]; Cylindrotelphusa [C. steniops]; Gecarcinucus H. Milne Edwards, 1844 [G. edwardsi Alcock, 1909, G. jacquemontii H. Milne Edwards, 1844]; Ghatiana [G. aurantiaca, G. hyacintha Pati \& Sharma 2014]; Gubernatoriana [G. basalticola, G. gubernatoris, G. pilosipes (Alcock, 1909), G. triangulus Pati \& Sharma 2014]; Inglethelphusa [I. fronto]; Lamella Bahir \& Yeo, 2007 [L. lamellifrons (Alcock, 1909)]; Pilarta [P. anuka]; Snaha [S. aruna, S. escheri (Roux, 1931)]; Travancoriana Bott, 1969 [T. charu Bahir \& Yeo, 2007, T. convexa (Roux, 1931), T. granulata Pati \& Sharma, 2014, T. kuleera Bahir \& Yeo, 2007, T. pollicaris (Alcock, 1909), T. schirnerae Bott, 1969]; Vanni Bahir \& Yeo, 2007 [V. ashini Bahir \& Yeo, 2007, V. deepta Bahir \& Yeo, 2007, V. giri Bahir \& Yeo, 2007, V. malabarica (Henderson, 1912), V. nilgiriensis (Roux, 1931), V. pusilla (Roux, 1931), V. travancorica (Henderson, 1912)]; Vela Bahir \& Yeo, 2007 [V. carli, V. pulvinata (Alcock, 1909), V. virupa Bahir \& Yeo, 2007].

Ecological requirements (habitat, food and feeding habits) are the same for A. cochleariformis and the sympatric species, V. carli (A.R. Sudha Devi, unpublished data). Both the species live in burrows adjoining to stagnant or running water and also in burrows away from water channels in open or shaded areas. Vela carli is primarily an omnivore or scavenger, but sometimes it shows opportunistic carnivore behaviour by preying upon small rats and water snakes. Suitable habitats containing optimum water levels (marshy land, paddy fields, betel nut or banana plantations) and availability of rich food sources, particularly from plant materials (including decaying leaves) and plant-associated animals (earthworms, insects), are the key factors for survival of these crabs in the Western Ghats of Wayanad district. In these circumstances, possibilities of occurrence of $A$. cochleariformis in other areas of Kerala and neighbouring states with similar conditions of habitat cannot be ignored.

Arcithelphusa cochleariformis is exposed to several natural and man-made threats. Predation of these crabs by birds and mammals is a noteworthy natural disturbance. Local tribal communities also consume large quantities of these crabs for their food. Applications of various pesticides including herbicides and insecticides may pose a serious threat to this species. Paddy fields and banana plantations in the region have already been contaminated by these chemicals whereas betel nut plantations are yet free from pesticide applications. Competition of the new species with the sympatric $V$. carli for habitat and food is also a threat. However, availability of adequate natural resources might be a reason for the successful colonization of these crabs. A severe threat to the new species is currently not recognized, which is evident from their abundant population and wide distribution in Wayanad district (A.R. Sudha Devi, unpublished data).

\section{Conclusions}

New taxa of freshwater crabs are described and compared with the related genera and species. In total, 36 species in 14 genera of gecarcinucid crabs are now recognized from the Western Ghats of India. More new taxa can be expected from this exceptionally biodiversity-rich area if the necessary surveys are done. The present discovery of the new species is useful for taxonomists as well as conservation managers.

\section{Competing interests}

The authors declare that they have no competing interests.

\section{Authors' contributions}

ARS collected the material and data. SKP conceived the study, prepared the illustrations and drafted the manuscript. Both SKP and ARS participated in the final identification, described the new taxa and approved the final manuscript.

\section{Authors' information}

SKP, Ph.D., is working as a carcinologist in the Zoological Survey of India, Western Regional Centre, Pune, Maharashtra. ARS, Ph.D., is an associate professor in the Department of Zoology and Research Centre, Mary Matha Arts and Science College, Mananthavady, Wayanad, Kerala.

\section{Acknowledgements}

We are thankful to the Director Dr. K. Venkataraman, Zoological Survey of India, Kolkata and the Officer-in-Charge Dr. P.S. Bhatnagar, Zoological Survey of India, Western Regional Centre, Pune for the constant encouragement and facilities.

\section{Author details}

'Zoological Survey of India, Western Regional Centre, Vidyanagar, Sector 29, P.C.N.T. Post, Akurdi, Pune 411 044, Maharashtra, India. ²Department of Zoology and Research Centre, Mary Matha Arts and Science College, Vemom P.O., Mananthavady 670 645, Kerala, India.

Received: 18 November 2014 Accepted: 31 March 2015 Published online: 17 April 2015

\section{References}

Alcock A (1910) Catalogue of the Indian decapod Crustacea in the collection of the Indian Museum. Part I. Brachyura. Fasciculus II. The Indian fresh-water crabs - Potamonidae. Indian Museum, Calcutta

Bahir MM, Yeo DCJ (2007) The gecarcinucid freshwater crabs of southern India (Crustacea: Decapoda: Brachyura). Raffles B Zool 16:309-354

Bott R (1970) Die Süßwasserkrabben von Europa, Asien, Australien und ihre Stammesgeschichte. Eine Revision der Potamoidea und Parathelphusoidea (Crustacea, Decapoda), vol 526. Abh Senckenb Naturforsch Ges, Frankfurt, pp 1-338 
Klaus S, Fernandez K, Yeo DCJ (2014) Phylogeny of the freshwater crabs of the Western Ghats (Brachyura, Gecarcinucidae). Zool Scr 43(6):651-660, doi:10.1111/zsc.12078

Ng PKL, Tay FWM (2001) The freshwater crabs of Sri Lanka (Decapoda: Brachyura: Parathelphusidae). Zeylanica 6(2):113-199

Pati SK, Sharma RM (2013) A new species of freshwater crab, Travancoriana granulata n. sp. (Brachyura: Gecarcinucidae) from the southern Western Ghats of India. Zoosyst Evol 89(2):275-281, doi:10.1002/zoos.201300013

Pati SK, Sharma RM (2014a) Description of Ghatiana, a new genus of freshwater crab, with two new species and a new species of Gubernatoriana (Crustacea: Decapoda: Brachyura: Gecarcinucidae) from the Western Ghat Mountains, India. J Nat Hist 48(21-22):1279-1298, doi:10.1080/00222933.2013.859315

Pati SK, Sharma RM (2014b) Freshwater crabs (Crustacea: Decapoda: Brachyura: Gecarcinucidae) in the collection of the Western Regional Centre, Pune. Rec Zool Surv India 363:1-44

Raghavan R, Dahanukar N, Philip S, lyer P, Kumar B, Daniel B, Molur S (2014) The conservation status of decapod crustaceans in the Western Ghats of India: an exceptional region of freshwater biodiversity. Aquatic Conserv: Mar Freshw Ecosyst. doi:10.1002/aqc.2490

Roux J (1931) Crustacés Décapodes d'eau douce de l'Inde méridionale. Rev Suisse Zool 38(1):31-62

\section{Submit your manuscript to a SpringerOpen ${ }^{\circ}$ journal and benefit from:}

- Convenient online submission

- Rigorous peer review

- Immediate publication on acceptance

- Open access: articles freely available online

- High visibility within the field

- Retaining the copyright to your article

Submit your next manuscript at $>$ springeropen.com 